\title{
Corneal Endothelial Cell Changes after Photorefractive Keratectomy for Low to Moderate Myopia With and Without Mitomycin-C
}

\author{
KARIM A. NASSAR, M.Sc.; HESHAM A. HASBY, M.D.; WALEED A. ALLAM, M.D. and \\ ADEL A. SELIEMA, M.D.
}

The Department of Ophthalmology, Faculty of Medicine, Tanta University, Egypt

\begin{abstract}
Background: Mitomycin-C was suggested for application during surface ablation procedures to reduce post-operative haze formation. It can effectively reduce haze formation and hence, improve the predictability of visual outcomes following refractive surgery. Despite these advantages, MMC can potentially damage all three main corneal cell types including epithelial (differentiated epithelium and limbal cells), stromal (keratocytes), and endothelial cells.
\end{abstract}

Aim of Study: To investigate the croneal endothelial cell changes after Photorefractive Keratectomy (PRK) with and without Mitomycin-C $0.02 \%$ for low to moderate myopia.

Patient and Methods: This prospective, randomized, comparative study included 60 eyes of 30 patients who were chosen from Ophthalmology Clinic at Tanta University Hospital and Shorouk Laser Vision Correction Centre for 6 month from December 2017 to May 2018 and scheduled for Photorefractive Keratectomy (PRK) using 193nm wavelength excimer laser system Allegretto EX500, (Wave Light Technologie., USA). These patients were randomly divided into two groups. Group (A) were scheduled for (PRK) with adjunctive mitomycin-C $0.02 \%$ and patients of Group (B) were scheduled for (PRK) without mitomycin-C. Informed consents were obtained from all study participants.

Results: In Group A the mean Endothelial Cell Density (ECD) was $2891.61 \pm 272.41$ and at three months after surgery was $2813.04 \pm 276.55$ cells $/ \mathrm{mm}^{2} \quad(p=0.289)$, pre-operative mean of Coefficient of Variation (CV) was $34.87 \pm 4.37$ and postoperatively was $34.70 \pm 4.06(p=0.877)$, the pre-operative mean of Central Corneal Thickness (CCT) was 523.00 \pm 26.14 rand $467.36 \pm 40.61$ pest-operatively $(p=0.001)$, the mean of hexagonality pre-operatively was $64.26 \pm 8.64 \%$ and $59.96 \pm$ $8.15 \%$ post-operatively ( $p=0.059$ ) which was statistically insignificant. In Group B the mean Endothelial Cell Density was (ECD) $2874.50 \pm 314.48$ and at three months after surgery was $2777.23 \pm 302.44 \mathrm{cells} / \mathrm{mm}^{2}(p=0.227)$, pre-operative mean of Coefficient of Variation (CV) was $33.49 \pm 4.98$ and postoperatively $33.55 \pm 4.10$ ( $p=0.962)$, pre-operative mean of central corneal thickness was $538.03 \pm 26.03$ and $484.50 \pm 20.55$

Correspondence to: Dr. Karim A. Nassar, The Department of Ophthalmology, Faculty of Medicine, Tanta University, Egypt post-operatively ( $p=0.001$ ), the mean of hexagonality preoperatively was $63.00 \pm 7.74$ and $61.43 \pm 7.29 \%$ post-operatively $(p=0.423)$

Conclusions: There's no significant effect on endothelium in patients underwent to PRK in low to moderate myopia with or without mitomycin-C. We can't judge the same results for patients with high myopia because the ablation depth will be more and theoretically the diffusion of mitomycin-C to endothelium would affect its function or count.

Key Words: Photorefractive Keratectomy - PRK - MMCEndothelial changes - Specular microscopy Myopia.

\section{Introduction}

RECENTLY although more LASIK than PRK procedures are performed, PRK remains an attractive option in refractive surgery for specific indications [1], including irregular or thin corneas; epithelial basement membrane disease (often called map-dot-fingerprint dystrophy); previous corneal surgery, such as penetrating keratoplasty and radial keratotomy; and treatment of some LASIK flap complications, such as incomplete or buttonholed flaps. Surface ablation eliminates the potential for stromal flap-related complications and may have a decreased incidence of post-operative dry eye [2].

Corneal haze, the major risk after PRK, decreased markedly with the use of adjunctive intraoperative mitomycin- $\mathrm{C}$ allowing treatment of higher levels of myopia with PRK [3] . Mitomycin-C (MMC) was first isolated from cultures of Streptomyces caespitosus by Hata in 1956. MMC was suggested for application during surface ablation procedures to reduce postoperative haze formation [4]. It can effectively reduce haze formation and hence, improve the predictability of visual outcomes following refractive surgery. Despite these 
advantages, MMC can potentially damage all three main corneal cell types including epithelial (differentiated epithelium and limbal cells), stromal (keratocytes), and endothelial cells.

Several studies have investigated the effect of a single intraoperative dose of MMC during refractive surgery on the corneal endothelium [4]. Some clinical and laboratory studies have reported significant corneal endothelial toxicity.

\section{Aim of work:}

The aim of this work is to study the corneal endothelial cell changes after photorefractivekeratectomy with mitomycin-C application in patients with low to moderate myopia.

\section{Study design:}

This prospective, randomized, comparative study included 60 eyes of 30 patients who were chosen from Ophthalmology Clinic at Tanta University Hospital and Shorouk Laser Vision Correction Centre and scheduled for Photo-Refractive Keratectomy (PRK). These patients were randomly divided into two groups. Group (A) were scheduled for (PRK) with adjunctive mitomycin-C $0.02 \%$ and patients of Group (B) were scheduled for (PRK) without mitomycin-C. Informed consents were obtained from all study participants.

\section{Patients and Methods}

This prospective, randomized, comparative study included 60 eyes of 30 patients who were chosen from Ophthalmology Clinic at Tanta University Hospital and Shorouk Laser Vision Correction Centre and scheduled for Photo-Refractive Keratectomy (PRK). These patients were randomly divided into two groups. Group (A) were scheduled for (PRK) with adjunctive mitomycin-C $0.02 \%$ and patients of Group (B) were scheduled for (PRK) without mitomycin-C. Informed consents were obtained from all study participants from December 2017 to May 2018.

Inclusion criteria include: Age from 18 to 40 years old, stable refraction of the patients in which no change of refraction more than \pm 0.5 diopter in 1 year, patients with low to moderate myopia with or without astigmatism from (1 to 6) diopters of M.R.S.E.

Exclusion criteria include: Contact lens wearers, patients with endothelial count $<2000$ cell $/ \mathrm{mm}^{2}$, dry eye syndrome, connective tissue diseases, corneal stromal dystrophies, patients having keratoconus or suspected topography, Fuch's corneal dystrophy, chronic use of certain medications such as (amiodarone hydrochloride, isotretinon), oneeyed patient, patients who are pregnant or breastfeeding, uncontrolled diabetis mellitus, diabetic retinopathy.

\section{Pre-operative evaluation:}

All patients included in the study were subjected to the following:

History taking including personal history, occupation, outdoor activity and contact lens wear.

Clinical examination: A-Visual acuity assessment (Uncorrected Distance Visual Acuity and Corrected Distance Visual Acuity) using the LogMAR chart, Manifest and cycloplegic refraction, Slit lamp biomicroscopy, Goldmann applanation tonometry, Fundus examination by indirect ophthalmoscopy, Specular microscopy was performed preoperatively using non-contact specular microscope SP-3000p (Topcon Inc., Tokyo, Japan). Analysis of the central Endothelial Cell Density (ECD), Coefficient of Variation (CV), Central Corneal Thickness (C CT) and percentage of cell Hexagonality (HEX) was performed, pre-operative corneal topography using the Pentacam rotating Scheimpflug camera (Oculus, Germany).

\section{Surgical procedure:}

PRK was performed using 193nm wavelength excimer laser system Allegretto EX500, (WaveLight Technologie., USA). At surgery, the corneal epithelium was removed mechanically using a rotating brush in all cases. Both groups had PRK by the same surgeon using an identical technique and nomogram. Patients in Group A received MMC for 12 seconds (regardless the ablation depth) followed by irrigation using $15 \mathrm{ml}$ of BSS before fitting the contact lens. In Group B after ablation, $15 \mathrm{ml}$ of chilled BSS was used to chill the cornea then a bandage contact lens was applied.

\section{Post-operative treatment after PRK:}

- Topical Moxifloxacin $0.5 \%$ eye drops four times daily for 6 days (Vigamox Alcon-cusi, USA), Topical prednisolone acetate $1 \%$ eye drops four times daily for four weeks then tapered gradually over two weeks. (Predforte, Allergan, Inc., U.S.A).

- Preservative free artificial tears carboxy-meththylcellulose $0.5 \%$ (Refresh-Plus, Allergan, Inc., U.S.A), Oral Vitamin-C 1000mg daily for one month following the procedure.

\section{Post-operative follow-up:}

Follow-up examinations were scheduled at day $1,3,7$, and 1, and 3 months including: Slit lamp biomicroscopy at 1 and 3 days after surgery for 
evaluation of epithelial healing and early detection of infection, from day 4 to day 7 for assessment of epithelial healing and contact lens removal, measurement of uncorrected distance visual acuity and corrected distance visual acuity at 1 and 3 month after surgery, measurement of intraocular pressure by Goldmann applantation tonometry at 1 and 3 months.

Specular microscopy at 3 month.

\section{Results}

\section{Statistical analysis:}

Statistical analysis data was analyzed using SPSS (Statistical Package for Social Sciences) v16.0 (SPSS Inc., Chicago, USA). Qualitative data was presented as number and percent. Comparison between groups was done by Chi-Square test. Quantitative data was presented as mean $\pm \mathrm{SD}$. Student $t$-test was used to compare between two groups. $p<0.05$ was considered to be statistically significant. The Coefficient of Repeatability (CR) can be calculated as 2 times the standard deviation of the differences between the two measurements (d2 and d1).

This prospective, randomized, comparative study included 60 eyes of 30 patients who were chosen from Ophthalmology Clinic at Tanta University Hospital and Shorouk Laser Vision Correction Centre and scheduled for Photo-Refractive Keratectomy (PRK). These patients were randomly divided into two groups. Group (A) were scheduled for (PRK) with adjunctive mitomycin-C $0.02 \%$ and patients of Group (B) were scheduled for (PRK) without mitomycin-C.

In Group (A) the mean age was $27.71 \pm 4.95$ years, while in Group (B) the mean age was $26.0 \pm$ 3.91 years. The difference between the two groups was not statistically significant $(p=0148)$.

Thirty eight females representing (63.4\%) and twenty two males representing (36.6\%) there was female dominance in the both groups.

Pre-operative mean of spherical equivalent in Group A was $-3.76 \pm 1.43$ and in Group B was -3.28 \pm 1.47 (D) there was no statistically difference between both groups $(p=0.210)$.

Pre-operative mean in Corrected Distance Visual Acuity (CDVA) in Group A was $0.02 \pm 0.07 \mathrm{Log}$ MAR and in Group B was zero $\pm 0.06 \log$ MAR, there was no statistically difference between both groups $(p=0.317)$.
Pre-operative mean K-max in Group A was 43.76 $\pm 1.48 \mathrm{D}$ and in Group B was 43.59 $\pm 1.24 \mathrm{D}$, there was no statistically difference between both groups $(p=0.625)$.

In Group A the mean Endothelial Cell Density (ECD) was $2891.61 \pm 272.41$ and at three months after surgery was $2813.04 \pm 276.55$ cells $/ \mathrm{mm}^{2}$ ( $p=$ 0.289), pre-operative mean of Coefficient of Variation (CV) was $34.87 \pm 4.37$ and post-operatively was $34.70 \pm 4.06(p=0.877)$, the pre-operative mean of Central Corneal Thickness (CCT) was $523.00 \pm$ 26.14 ran $467.36 \pm 40.61$ poperatively $(p=$ 0.001 ), the mean of hexagonality pre-operatively was $64.26 \pm 8.64 \%$ and $59.96 \pm 8.15 \%$ postoperatively $(p=0.059)$ which was statistically insignificant.

In Group B the mean Endothelial Cell Density was (ECD) $2874.50 \pm 314.48$ and at three months after surgery was $2777.23 \pm 302.44$ cells $/ \mathrm{mm}^{2}$ $(p=0.227)$, pre-operative mean of Coefficient of Variation (CV) was $33.49 \pm 4.98$ and postoperatively $33.55 \pm 4.10$ ( $p=0.962$ ), pre-operative mean of central corneal thickness was $538.03 \pm 26.03$ and 484.50 \pm 20.55 spo-operatively $(p=0.001)$, the mean of hexagonality pre-operatively was $63.00 \pm 7.74$ and $61.43 \pm 7.29 \%$ post-operatively $(p=0.423)$.

Mean ablation depth in Group A was $61.33 \pm$ $21.42 \mathrm{~m}$ and in Group B was $58.93 \pm 19.40 \mathrm{~m}$, there was no statistically difference between both groups $(p=0.651)$.

\section{Visual acuity and refraction:}

The post-operative range of spherical equivalent in Group-A varying from $(-0.5$ to +0.25$)$ and in Group-B from -1.00 to +0.25 (D).

The post-operative uncorrected distance visual acuity ranged from -0.1 to 0.1 Log MAR in Group$A$ and from 0 to 0.3 Log MAR in Group-B and there was statistically significant difference $(p=$ 0.001 ). While the post-operative best corrected distance visual acuity in Group-A ranged from -0.1 to 0 Log MAR and from -0.1 to 0.1 Log MAR in Group-B and there was no statistically difference between the two groups $(p=1.0)$.

In our study corneal haze occurred in 5 eyes of Group A, 4 eyes were grade +0.5 and one eye was grade +1 representing $16.6 \%$ of total 30 eyes of this group and in Group B occurred in 19 eyes 10 of them were grade $+0.5,6$ eyes were grade $+1,2$ eyes were grade +2 and one eye was grade 3 representing $63 \%$ of total 30 eyes of this group. There was statistically significant difference between the two groups $(p=0.006)$. 
Table (1): Demographic data (age).

\begin{tabular}{lll}
\hline Age & Group (A) & Group (B) \\
\hline Range (years) & $20-35$ & $21-36$ \\
Mean \pm SD & $27.71 \pm 4.95$ & $26.0 \pm 3.91$ \\
$t$-test & & 2.156 \\
$p$-value & 0.148 & \\
\hline
\end{tabular}

Table (2): Demographic date (sex).

\begin{tabular}{clll}
\hline Sex & Group A & Group B & Total \\
\hline Male: & & & \\
$\mathrm{N}$ & 8 & 14 & 22 \\
$\%$ & $26.6 \%$ & $46.7 \%$ & $36.6 \%$ \\
Female: & & & \\
$\mathrm{N}$ & 22 & 16 & 38 \\
$\%$ & $73.3 \%$ & $53.3 \%$ & $63.4 \%$ \\
Total: & & & \\
$\mathrm{N}$ & 30 & 30 & 60 \\
$\%$ & $100.0 \%$ & $100.0 \%$ & $100.0 \%$ \\
Chi-square: & & & \\
$\chi^{2}$ & & 4.083 & \\
$p$-value & & $0.043 *$ & \\
\hline
\end{tabular}

Table (3): Comparison between pre and post-operative specular microscopy data in Group A.

\begin{tabular}{lllll}
\hline Group (A) & Range & Mean $\pm \mathrm{SD}$ & $t$-test & $p$-value \\
\hline $\begin{array}{l}\text { Cell density: } \\
\quad \text { Pre }\end{array}$ & $2447-3475$ & $2891.61 \pm 272.41$ & 1.147 & 0.289 \\
$\quad$ Post & $2370-3407$ & $2813.04 \pm 276.55$ & & \\
$\begin{array}{l}\text { Coeffecient of } \\
\text { variation: }\end{array}$ & & & & \\
$\quad$ Pre & $24.3-42$ & $34.87 \pm 4.37$ & 0.024 & 0.877 \\
$\quad$ Post & $28.1-41.2$ & $34.70 \pm 4.06$ & & \\
Central corneal & & & & \\
thickness: & & & & \\
$\quad$ Pre & $485-595$ & $523.00 \pm 26.14$ & 37.164 & $0.001^{*}$ \\
$\quad$ Post & $386-553$ & $467.36 \pm 40.61$ & & \\
$\quad$ Hexagonality: & & & & \\
$\quad$ Pre & $48-80$ & $64.29 \pm 8.64$ & 3.707 & 0.059 \\
$\quad$ Post & $45-78$ & $59.96 \pm 8.15$ & & \\
\hline
\end{tabular}

Table (4): Comparison between pre, post-operative specular microscopy data in Group B.

\begin{tabular}{lllll}
\hline Group (B) & Range & Mean \pm SD & $t$-test & $p$-value \\
\hline $\begin{array}{l}\text { Cell density: } \\
\quad \text { Pre }\end{array}$ & $2224-3400$ & $2874.50 \pm 314.48$ & 1.491 & 0.227 \\
$\quad$ Post & $2200-3312$ & $2777.23 \pm 302.44$ & & \\
$\begin{array}{l}\text { Coeffecient of } \\
\text { variation: }\end{array}$ & & & & \\
$\quad$ Pre & $23.1-43$ & $33.49 \pm 4.98$ & 0.002 & 0.962 \\
$\quad$ Post & $24.5-41$ & $33.55 \pm 4.10$ & & \\
$\quad \begin{array}{l}\text { Central corneal } \\
\text { thickness: }\end{array}$ & & & & \\
$\quad$ Pre & $496-575$ & $538.03 \pm 26.03$ & 78.167 & $0.001^{*}$ \\
$\quad$ Post & $454-530$ & $484.50 \pm 20.55$ & & \\
Hexagonality: & & & & \\
$\quad$ Pre & $50-83$ & $63.00 \pm 7.74$ & 0.652 & 0.423 \\
$\quad$ Post & $49-76$ & $61.43 \pm 7.29$ & & \\
\hline
\end{tabular}

Table (5): Comparison between two studied groups according to ablation depth.

\begin{tabular}{lcccc}
\hline Ablation depth & Range & Mean \pm SD & $t$-test & $p$-value \\
\hline Group A & $30-92$ & $61.33 \pm 21.42$ & 0.207 & 0.651 \\
Group B & $30-99$ & $58.93 \pm 19.40$ & & \\
\hline
\end{tabular}

Table (6): The pre-operative mean of spherical equivalent $-3.53 \pm 1.33$

\begin{tabular}{lcc}
\hline & Range & Mean \pm SD \\
\hline Spherical equivalent & $-6.5 \pm-1.50$ & $-3.53 \pm 1.33$ \\
\hline
\end{tabular}

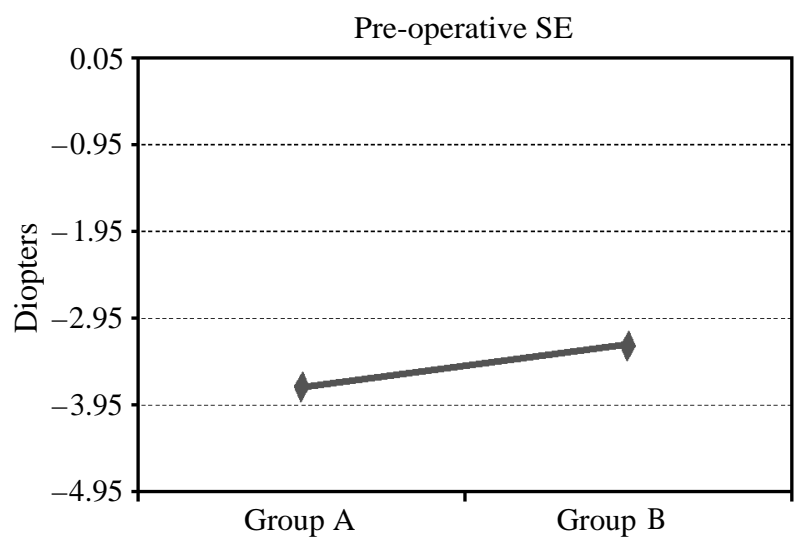

Fig. (1): Pre-operative Spherical equivalent in both groups.

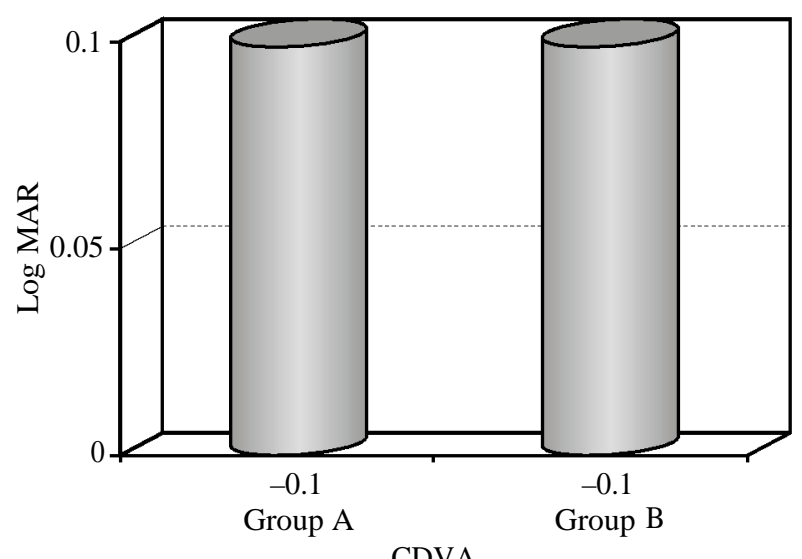

Fig. (2): Pre-operative mean in K-max reading.

\section{Discussion}

In our study, 60 eyes of 30 patients were selected and randomly divided into two groups. Group A underwent to PRK with adjuvant use of mitomycinC $0.02 \%$ and Group B underwent to PRK without mitomycin-C. Mean pre-operative spherical equivalent of the patients in Group A was $-3.76 \pm 1.43$ (D) and in Group B was $-3.28 \pm 1.47$ (D), and the mean in ablation depth in Group A was $61.33 \pm 21.42$ and in Group B was 58.93 \pm 19.40 
In Group A we found that reduction in cell density was $2.74 \%$, there was an insignificant change in cell morphology including coefficient of variation which was reduced insignificantly to $0.17 \%$, and the reduction in hexagonality was $4.33 \%$.

On Group B we found the reduction in cell density was $3.37 \%$, there was an insignificant change in cell morphology including coefficient of variation which was reduced $-0.06 \%$ and reduction of hexagonality was $1.57 \%$.

We found reduction in UCDVA in Group B in $60 \%$ of the patient varying from 0.3 to 0.1 LOGMAR with corneal haze in these patients varying from 0.5 to +3 . On the other hand Group A reduction in UCDVA was less than $15 \%$ none of the patients get UCDVA less than 0.1 LOGMAR. Corneal haze found in these patients was less than +1 .

Hong SJ. et al., [5], studied the toxic effects of mitomycin-C on cultured porcine keratocytes and endothelial cells were estimated by MTT, $3 \mathrm{H}-$ thymidine uptake and cellular counting assay methods. It was found that Mitomycin-C caused a dosedependent toxic effect to keratocytes and endothelial cells. Both cells were treated with Mitomycin$\mathrm{C}$ at the concentration ranging from 100, 10, 1, 0.1 to $0.01 \mathrm{pg} / \mathrm{ml}$ for $3 \mathrm{~min}, 5 \mathrm{~min}$ or $100 \mathrm{~min}$. The $50 \%$ inhibitory dose (ID 50) of Mitomycin-C to keratocytes and endothelial cells as measured by MTT assay was $0.40,0.18,0.16 \mathrm{mg} / \mathrm{ml}$ and 0.27 , $0.15,0.14 \mathrm{mg} / \mathrm{ml}$, respectively, after 3,5 and 100 minutes drug treatment. The ID 50 for keratocytes and endothelial cells as measured by 3 Hthymidine uptake immediately, 1 day and 7 days after 100 minutes Mitomycin-C treatment was 0.3, 0.0002, $143.2 \mathrm{pg} / \mathrm{ml}$ and $45.1,101.1,450.2 \mathrm{pg} / \mathrm{ml}$, respectively. The ID 50 for keratocytes and endothelial cells as measured by cellular counting 1 day and 7 days after Mitomycin-C treatment was 232.5, $109.7 \mathrm{pg} / \mathrm{ml}$ and $239.9,367.5 \mathrm{pg} / \mathrm{ml}$, respectively. It is concluded that Mitomycin-C is more toxic to cellular proliferation in cultured corneal keratocytes than in endothelial cells.

Zare M. et al., [6], in a prospective interventional case series of patients with moderate myopia (spherical equivalent of refractive error ranged from -4.0 to -8.0D) underwent PRK with a single intraoperative application of MMC $0.02 \%$ for 40 seconds. Specular microscopy was performed preoperatively and repeated 6 months after surgery. The study was conducted on 42 eyes of 21 participants with mean age of $26.2 \pm 6.3$ years. The mean pre- operative spherical equivalent of refractive error was $-5.2 \pm 1.2 \mathrm{D}$ which was reduced to $-0.4 \pm 0.5 \mathrm{D}$ post-operatively $(p<0.001)$. The mean ECD was reduced insignificantly from $2920 \pm 363$ cells $/ \mathrm{mm}^{2}$ pre-operatively to $2802 \pm 339$ cells $/ \mathrm{mm}^{2}$ postoperatively $(p=0.59)$. Similarly, there was no significant change in Mean Cell Area (MCA) or Coefficient of Variation (CV) at six months ( $p=0.76$ and 0.52 , respectively). They concluded that application of MMC $0.02 \%$ for 40 seconds during PRK in patients with moderate myopia did not significantly affect central corneal endothelial cell density and morphology after the 6 months follow-up period.

Lee et al., [7], in a retrospective non-comparative case series including 536 patients (1011 eyes) who had PRK with intraoperative application of MMC $0.02 \% 30$ seconds to 2 minutes; the mean preoperative SE was -7.82 diopters $\pm 2.64 ; 72 \%$ of eyes (732) were more than $-6.00 \mathrm{D}$, and $28 \%$ (287) were more than $-9.00 \mathrm{D}$. The mean follow-up was 13 months (range 6 to 27 months). Six months post-operatively, the mean post-operative SE was $0.14 \pm 0.62 \mathrm{D} ; 86 \%$ were within $\pm 0.50 \mathrm{D}$ and $93 \%$ were within $\pm 1.00 \mathrm{D}$ of desired refraction. Eightysix percent had $20 / 20$ or better visual acuity, and $98 \%$ were $20 / 40$ or better. Regression of more than $1.00 \mathrm{D}$ occurred in 78 eyes $(7.6 \%)$, and it was more common in eyes with a pre-operative SE of $-9.00 \mathrm{D}$ or worse (18\%). Haze occurred in 32 eyes $(3.17 \%)$, but in most cases it was limited to grade 1 . Grades 2 and 3 haze occurred in 3 eyes and 2 eyes, respectively. The post-operative endothelial cell density measured by specular microscopy did not show a significant difference from pre-operative measurements. Delayed epithelial healing was observed in 2 eyes and concluded that endothelial cell density remained unchanged after 16 months.

Zhao et al., [8], evaluated the effect of (MMC) on corneal endothelial cells after Laser-Assisted Sub-Epithelial Keratectomy (LASEK). One hundred seventy-four eyes of 89 patients who did not previously wear contact lenses were treated with LASEK with intraoperative use of topical MMC $0.02 \%$ (15 seconds). Noncontact corneal specular microscopy was performed in all eyes preoperatively, 1, 3, and 6 months after surgery. Preoperatively, the mean central endothelial density was 2755 cells $/ \mathrm{mm}^{2} \pm 373$ (SD), the mean coefficient of variation was $31.45 \pm 8.26$, and the mean hexagonality was $66.03 \pm 25.83$. After LASEK, there were no statistically significant changes in cell density, CV, or hexagonality ( $p>.05)$. Multiple linear regression did not identify ablation depth or RSB thickness as being predictive of a change in 
CCD, CV, or HEX ( $p>.05)$. No significant change in central endothelial cell density or morphology at least 6 months after a 15 second application of MMC $0.02 \%$. Additionally, they did not observe any significant correlation between ablation depth and changes in endothelial cell density or morphology.

Shojaei et al., [9], in prospective randomized double masked clinical trial studied the safety and efficacy of Mitomycin-C application for 5 seconds after PRK in low myopia. The study was conducted on 184 eligible eyes subdivided into MMC group and control group without MMC. The postoperative haze grade was significantly lower in the MMC group $(p=0.01)$. The mean endothelial cell density was not significantly different between the MMC group and the control group preoperatively $\left(2879.97 \mathrm{cells} / \mathrm{mm}^{2} \pm 298.04\right.$ [SD] versus $2819.69 \pm 303.89$ cells $\left./ \mathrm{mm}^{2} ; p=0.22\right)$ or 6 months post-operatively $\left(2878.79 \pm 283.04\right.$ cells $/ \mathrm{mm}^{2}$ versus $2878.79 \pm 283.04$ cells $/ \mathrm{mm}^{2} ; p=0.25$ ). No notable ocular complication occurred throughout the study and they concluded that the short time application of MMC was safe and effective in preventing haze formation in eyes having PRK with an ablation depth less than 65 micrometers compared to control group in duration up to 6 months.

Nasiri N. et al., [10], in non-randomized trial on 162 eyes with bilateral low to moderate myopia in which 76 eyes were treated with MMC, found that eyes treated with MMC and untreated eyes were comparable in post-operative visual acuity and refraction. The mean endothelial cell density was $2525 \pm 457 \mathrm{cells} / \mathrm{mm}^{2}$ before surgery, $2332 \pm 643$ cells $/ \mathrm{mm}^{2}$ after 3 months and $2283 \pm 597$ cells $/ \mathrm{mm}^{2}$ after 12 months, representing a cell loss of $9.5 \%$ and $10.0 \%$, respectively. The cell loss was marginally significant after 3 months $(p=0.052)$ and significant at 12 months ( $p=0.027$ ). The cell loss from 3 to 12 months was non-significant $(p=0.40)$. The mean pre-operative percentage of hexagonal cells was $60 \% \pm 5.7$ before surgery, decreasing to $52 \%$ \pm 9.8 three months post-operatively $(p=0.015)$. However, after 12 months, the figure increased to $55 \% \pm 8.2$, and was no longer significantly different from the pre-operative value $(p=0.07)$. Mean variation of cell size (CV) was $29.5 \% \pm 3.3$ before surgery, increasing to $31.7 \% \pm 5.4$ after 3 months, and $32.6 \% \pm 8.1$ after 12 months. This variation was non-significant ( $p=0.08$ and 0.13 ). Mean CCT was $527-22$ before surgery, $531-4$ at 3 months, and $531 \mathrm{~m}-30$ at 12 months after surgery. These differences were non-significant ( $p=0.80$ and 0.34 , respectively).
Garweg et al., [11], showed that direct application of MMC (on human corneas maintained in vitro and on endothelial cell cultures) at concentrations of $0.1 \mathrm{mg} / \mathrm{ml}(0.01 \%)$ or lower did not result in endothelial toxicity, whereas application of $0.2 \mathrm{mg} / \mathrm{ml}(0.02 \%)$ MMC rapidly induced edema with marked ultra-structural changes.

Song JS et al., [12], measured MMC concentration in the aqueous humor after application of $0.02 \% \mathrm{MMC}$ for 2 minutes and found an aqueous humor concentration much lower than $0.002 \%$. Nevertheless, this small concentration had been shown to cause cross-linking and double-strand breaks of corneal endothelial DNA in goat corneas.

Morales AJ et al., [13], conducted a randomized clinical trial on 18 eyes of 9 participants with myopia between 1.75 and 6.25D. Fellow eyes were randomly assigned to PRK with MMC $0.02 \%$ or BSS for 30 seconds, there was no significant difference in the pre-operative endothelial cell count between the two groups: MMC group $2835 \pm 395$, control group 2779 $\pm 492,(p=62)$. In the control group, at one month and three months the difference in the endothelial cell count was not statistically significant ( $p=0.27, p=0.14$, respectively). However, in the MMC group the endothelial cell loss was statistically significant: At one month $14.7 \pm 5.1 \%$ and at three months $18.2 \pm 9.0 \%(p=0.0006, p=$ 0.002 , respectively). They concluded that the use of intraoperative topical MMC $0.02 \%$ for 30 seconds after PRK may affect the endothelial cell count. The sample size of this study was too small to draw a conclusive result.

\section{Conclusion:}

There's no significant effect on endothelium in patients underwent to PRK in low to moderate myopia with or without mitomycin-C. We can't judge the same results for patients with high myopia because the ablation depth will be more and theoretically the diffusion of mitomycin-C to endothelium would affect its function or count.

\section{References}

1- TROKEL S.L., SRINIVASAN R. and BRAREN B.: Excimer laser surgery of the cornea. Am. J. Ophthalmol., Dec., 96 (6): 710-5, 1983.

2- MAJMUDAR P.A., FORSTOT S.L., DENNIS R.F., NIRANKARI V.S., DAMIANO R.E., BRENART R., et al.: Topical Mitomycin-C for subepithelial fibrosis after refractive corneal surgery. Ophthalmology, 107 (1): 8994, 2000.

3- CARONES F., VIGO L., SCANDOLA E. and VACCHINI L.: Evaluation of the prophylactic use of Mitomycin-C to inhibit haze formation after photo refractive keratectomy. 1 Cataract Refract. Surg., 28 (12): 2088-95, 2002. 
4- McDERMOTT M.L., WANG J. and SHIN D.H.: Mitomycin and the human corneal endothelium. Arch. Ophthalmol., 112: 533-7, 1994.

5- HONG S.J., WU K.Y., HUANG H.T., LIN C.P. and CHEN C.W.: Toxic effects of Mitomycin-C on cultured corneal keratocytes and endothelial cells. J. Ocul. Pharmacol. Ther., 15: 401-11, 1999

6- ZARE M., JAFARINASAB M.R., FEIZI S. and ZAMANI M.: The effect of Mitomycin-C on corneal endothelial cells after photorefractive keratectomy. J. Ophthalmic. Vis. Res., 6 (1): 8-12, 2011.

7- LEE D.H., CHUNG H.S., JEON Y.C., BOO S.D., YOON Y.D. and KIM J.G.: Photorefractive keratectomy with intraoperative Mitomycin-C application. J. Cataract. Refract. Surg., 31: 2293-8, 2005.

8- ZHAO L.Q., WEI R.L., MA X.Y. and ZHU H.: Effect of intraoperative Mitomycin-C on healthy corneal endothelium after laser-assisted subepithelial keratectomy. J. Cataract Refract Surg., 34: 1715-9, 2008.

9- SHOJAEI A., RAMEZANZADEH M., SOLEYMANJAHI S., ALMASI-NASRABADI M., REZAZADEH P. and ESLANI M.: Short-time Mitomycin-C application during photorefractive keratectomy in patients with low myopia. J. Cataract Refract Surg., 39 (2): 197-203, 2013.

10- NASSIRI N., FARAHANGIZ S., RAHNAVARDI M., RAHMANI L. and NASSIRI N.: Corneal endothelial cell injury induced by Mitomycin-C in photorefractive keratectomy: Nonrandomized controlled trial. J. Cataract Refract Surg., 34: 902-908, 2008.

11- GARWEG J.G., WEGMANN-BURNS M. and GOLDBLUM D.: Effects of daunorubicin, mitomycin C, azathioprine and cyclosporin $\mathrm{A}$ on human retinal pigmented epithelial, corneal endothelial and conjunctival cell lines. Graefes Arch. Clin. Exp. Ophthalmol., 244: 382-9, 2006.

12- SONG J.S., KIM J.H., YANG M., SUL D. and KIM H.M.: Mitomycin-C concentration in cornea and aqueous humor and apoptosis in the stroma after topical Mitomycin-C application: Effects of Mitomycin-C application time and concentration. Cornea, 26: 461-7, 2007.

13- MORALES A.J., ZADOK D., MORA-RETANA R. MARTÍNEZ-GAMA E., ROBLEDO N.E. and CHAYET A.S.: Intraoperative mitomycin and corneal endothelium after photorefractive keratectomy. Am. J. Ophthalmol., 142: 400-4, 2004.

\section{تغيرات الطبقة المبطنة للقرثية بعد عملية كشط القرنية فى حالات قصر النظر المنخفض والمتوسط لمالهي}

الجراحة وعدم وجود آلّ عمليات الليز السطحى (كثط القرنية) فى الثمانينات ثم تدنت شهرتها فى التسعينات بعد طفرة الليزك نتيجة سرعة الإلتئام بعد

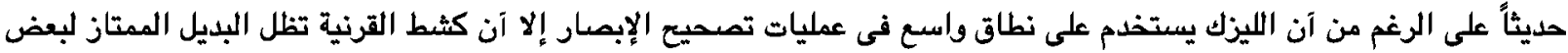

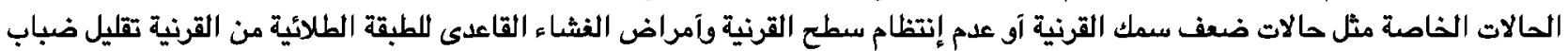

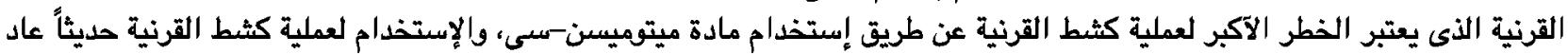

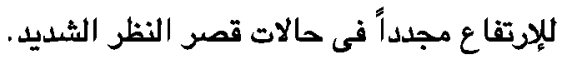

تم إكتثاف مادة (ميتوميسن سى) فى ستينات القرن الماضى وكانت تقترح لتطبيق إستخداهها آثناء عمليات الليزر السطحى وذلك لتقليل ضبابية القرنية والذى نجحت فيه بصودة كبيرة، ولكن تناولت بعض الدراسات التآثير السام لهذه المادة على الطبقات المختلفة القرنية ومنها الطبقة المبطنة. - ايه

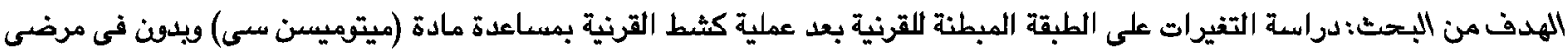
قصر النظر المنخفض إلى المتوسط بواسطة المجهز البراق غير التلامسى (إس بى . .. ب بى).

المرضى وطرق البحث: تم إجراء هذه الدراسة بمستشفيات جامعة طنطا وبمركز عيون الثرقق على مدى ستة آثهر على عدد .7 عين.

الإستتناج: آنه ليس هناك تآثير ملحوظ على الطبقة المبطنة للقرنية بعد عملية كثط القرنية فى حالات قصر النظر المنخفض والمتوسط فى آى من المجموعتين. 